\section{Efeitos de Concentrações Crescentes de Lidocaína Hiperbárica, Administradas no Espaço Subaracnóideo, sobre a Me- dula Espinhal e as Meninges. Estudo Experimental em Cães}

(Rev Bras Anestesiol, 2006;56:253-262)

\section{Senhor Editor,}

Trabalho recentemente publicado na RBA com doses crescentes de lidocaína hiperbárica $(5 \%, 7,5 \%$ e $10 \%$, todas com solução glicosada a 7,5\%) demonstrou que a concentração de $5 \%$ é segura para a prática da raquianestesia e que concentrações superiores a 7,5\% determinaram alterações histológicas sobre a medula espinhal, mas não sobre as meninges ${ }^{1}$. Este trabalho experimental veio corroborar a minha idéia de que a lidocaína hiperbárica nas concentrações de 1,5\% e $2 \%$ é segura para raquianestesia ${ }^{2}$ e que não pode ser retirada do arsenal do anestesiologista. A Cirurgia evoluiu, e, portanto, a Anestesiologia não pode se dar ao luxo de não possuir um anestésico para procedimentos de curta duração, como cura cirúrgica de incontinência urinária, cistoscopia, curetagem, procedimentos anorretais e outros.

Em estudo epidemiológico foram identificados diversos fatores de riscos no desenvolvimento de sintomas neurológicos temporários (SNT) com a lidocaína como: cirurgia ambulatorial, obesidade e posição de litotomia ${ }^{3}$. Trinta pacientes, estado físico ASA I e II, foram aleatoriamente selecionados para receberem $30 \mathrm{mg}$ de lidocaína hiperbárica a $1,5 \%$ ou $2 \%$, submetidos à raquianestesia com agulha $27 \mathrm{G}$ ponta de Quincke para procedimentos em regime ambulatorial e na posição de litotomia. Os pacientes foram examinados quanto ao bloqueio sensitivo, bloqueio motor, duração do bloqueio e os pacientes contatados às 24,48 e 72 horas após os procedimentos com relação ao aparecimento de SNT. Não houve diferença entre a latência, dispersão cefálica da anestesia, graus de bloqueio motor e duração da cirurgia, porém a maior concentração da lidocaína (2\%) proporcionou duração significativamente mais longa. Não foi observado nenhum caso de SNT ou seqüela neurológica permanente.

A lidocaína é um dos mais versáteis anestésicos locais, sendo utilizada para infiltração, bloqueio de nervos periféricos, anestesia peridural, raquianestesia e anestesia tópica. A lidocaína por via venosa tem valor como antidisrítmico, analgésico e supressão da tosse. É potente, com rápido início de ação e duração moderada. A lidocaína foi lançada para raquianestesia em 1948, na concentração de $2 \%$ com glicose a $10 \%$, proporcionando anestesia satisfatória para citoscopia e procedimentos perineais ${ }^{4}$. Em 1954, o laboratório Astra introduziu a solução de lidocaína a 5\% hiperbárica para raquianestesia conquistando aceitação mundial. Em 1991, foram relatados quatro casos de síndrome de cauda eqüina associada a lidocaína $5 \%$, microcateter, tetracaína a $1 \%$ e cateter de peridural ${ }^{5}$. Observe que as doses empregadas extrapolaram àquelas habitualmente empregadas na prática clínica. Em 1993, foram relatados os primeiros casos de SNT após raquianestesia com lidocaína $5 \%{ }^{6}$. Embora diversos estudos documentem a presença de SNT, sua exata etiologia não foi ainda definida. Dados laboratoriais indicam o potencial neurotóxico da lidocaína ${ }^{7}$ e esta neurotoxicidade é concentração dependente ${ }^{2,8}$. Diversos estudos mostraram que a incidência de SNT não diminuiu com soluções de $2 \%, 1 \%$ ou $0,5 \%{ }^{9-11}$, mas que o limite da dose total pode ter efeito benéfico ${ }^{12}$. A incidência de SNT após baixas doses de lidocaína (20 mg) associada ao fentanil (25 $\mu \mathrm{g}$ ) foi significativamente menor do que com a dose convencional $(50 \mathrm{mg})^{12}$. Em outro trabalho utilizando lidocaína a $3 \%$ com dose entre 30 e $45 \mathrm{mg}$ para cirurgias anorretais, foi confirmado a baixa incidência desses problemas ${ }^{13}$.

Desde 1998 utilizo as soluções de lidocaína a 1,5\% e a $2 \%$ com glicose a $8 \%{ }^{2}$. Comparando $4 \mathrm{~mL}$ de lidocaína a $1,5 \%$ hiperbárica $(60 \mathrm{mg}$ ) com o mesmo volume de lidocaína a $2 \%$ hiperbárica $(80 \mathrm{mg}$ ) foi demonstrado que a dispersão e a duração da raquianestesia foram mais dependentes da dose do que da concentração do anestésico local, não tendo sido observado nenhum caso de SNT, nem lesão neurológica definitiva ${ }^{2}$.

Nesse estudo piloto, com apenas 30 pacientes, não foi observado nenhum caso de SNT com baixas doses de ambas as soluções de lidocaína hiperbárica em posição de litotomia e em regime ambulatorial. Estudos aleatórios e duplamente encobertos são necessários para definitivamente podermos voltar a utilizar a lidocaína hiperbárica com a mesma segurança e tranqüilidade que tínhamos em anos anteriores.

Atenciosamente,

Luiz Eduardo Imbelloni, TSA

Av. Epitácio Pessoa, 2.356/203

22.411-070 - Rio de Janeiro, RJ

E-mail: dr.imbelloni@terra.com.br

\section{Effects of Increasing Spinal Hyperbaric Lidocaine Concentrations of Spinal Cord and Meninges. Experimental Study in Dogs}

(Rev Bras Anestesiol, 2006; 56:253-262)

Dear Editor,

A study published recently in RBA on increasing doses of hyperbaric lidocaine $(5 \%, 7.5 \%$, and $10 \%$, all in glucose $7.5 \%$ in water) demonstrated that the $5 \%$ concentration is safe to 
be used in subarachnoid anesthesia and that concentrations higher than $7.5 \%$ lead to histological changes in the spinal cord but not in the meninges ${ }^{1}$. This experimental study corroborated my idea that $1.5 \%$ and $2 \%$ hyperbaric lidocaine is safe to be used in epidural anesthesia ${ }^{2}$ and that it cannot be removed from the anesthesiologists' arsenal. Surgery has evolved; therefore, anesthesiology cannot afford the luxury of not having an anesthetic for short duration procedures, such as surgery for urinary incontinence, cystoscopy, curettage, anorectal procedures, and others.

An epidemiological study identified several risk factors for the development of transient neurological symptoms (TNS) with lidocaine, such as: outpatient surgery, obesity, and lithotomy position ${ }^{3}$. Thirty patients, physical status ASA I and II, were randomized assigned to undergo subarachnoid anesthesia with $30 \mathrm{mg}$ of $1.5 \%$ or $2 \%$ hyperbaric lidocaine, using a $27 \mathrm{G}$ Quicke tip needle, as outpatients, in the lithotomy position. Patients were evaluated regarding sensitive block, motor block, duration of the anesthesia, and the development of TNS 24, 48, and 72 hours after the procedure. There were no differences among latency, cephalic spread of the anesthetic, degree of motor anesthesia, and length of the surgical procedure, but the duration with the higher concentration of lidocaine (2\%) was longer. There were no cases of TNS or permanent neurologic deficits.

Lidocaine is one of the most versatile anesthetics, being used for infiltration, peripheral nerve blocks, epidural anesthesia, and local anesthesia. Intravenous lidocaine is used as antiarrhythmic, analgesic, and cough suppressant. It is potent, with a fast onset of action, and moderate duration. Lidocaine was first used in subarachnoid anesthesia in 1948, at the $2 \%$ concentration with glucose, providing adequate anesthesia for cystoscopy and perineal surgical procedures ${ }^{4}$. In 1954, the laboratory Astra introduced $5 \%$ hyperbaric lidocaine for subarachnoid anesthesia, which gained worldwide acceptance.

In 1991, four cases of cauda equina syndrome associated with $5 \%$ lidocaine, microcatheter, $1 \%$ tetracaine and epidural catheter were reported ${ }^{5}$. Notice that the doses used extrapolate those normally used in clinical practice. In 1993, the first cases of TNS after subarachnoid anesthesia with $5 \%$ lidocaine were reported ${ }^{6}$. Even though several studies reported the presence of TNS, its etiology has not been defined yet. Laboratory data indicate the neurotoxic potential of lidocaine ${ }^{7}$, and this neurotoxicity is concentration-dependent ${ }^{2,8}$. Several studies showed that the incidence of TNS does not decrease with $2 \%, 1 \%$, or $0.5 \%$ concentrations ${ }^{9-11}$, but that the limit of the total dose may be benefic ${ }^{12}$. The incidence of TNS after low doses of lidocaine $(20 \mathrm{mg}$ ) associated with fentanyl $(25 \mathrm{mg})$ was significantly lower than with the conventional dose $(50 \mathrm{mg}){ }^{12}$. Another study using $3 \%$ lidocaine with doses between 30 and $45 \mathrm{mg}$ for anorectal surgeries confirmed the low incidence of those problems ${ }^{13}$. I have used $1.5 \%$ and $2 \%$ lidocaine with glucose $8 \%$ in since $1998^{2}$. It was demonstrated, comparing $4 \mathrm{~mL}$ of $1.5 \%$ hyperbaric lidocaine $(60 \mathrm{mg})$ with the same volume of $2 \%$ hyperbaric lidocaine $(80 \mathrm{mg})$, that the spread and duration of the subarachnoid anesthesia depended more on the dose than on the concentration of the local anesthetic, and there were no cases of TNS or permanent neurologic deficits ${ }^{2}$. In this study, with only 30 patients, there were no cases of TNS with low doses of both concentrations of hyperbaric lidocaine with the patient in the lithotomy position and as an outpatient. It is necessary to perform randomized, double blind studies so we can use hyperbaric lidocaine with the same safety and peace of mind that we had in the past.

Sincerely,

\author{
Luiz Eduardo Imbelloni, TSA, M.D. \\ Av. Epitácio Pessoa, 2356/203 \\ 22.411-070 Rio de Janeiro, RJ \\ E-mail: dr.imbelloni@terra.com.br
}

\section{REFERÊNCIAS - REFERENCES}

01. Pires SRO, Ganem EM, Marques M et al. - Efeitos de concentrações crescentes de lidocaína hiperbárica, administradas no espaço subaracnóideo, sobre a medula espinhal e as meninges. Estudo experimental em cães. Rev Bras Anestesiol, 2006;56:253262.

02. Imbelloni LE, Carneiro ANG - Estudo comparativo entre lidocaína a $1,5 \%$ e a $2 \%$ com glicose para raquianestesia. Rev Bras Anestesiol, 1999;49:9-13.

03. Freedman JM, Li DK, Drasner K et al. - Transient neurologic symptoms after spinal anesthesia: an epidemiologic study of 1,863 patients. Anesthesiology 1998;89:633-641.

04. Gordh T - Xylocaine. A new local analgesia. Anaesthesia, 1949;4:4.

05. Rigler ML, Drasner K, Krejcie TC et al. - Cauda equina syndrome after continuous spinal anesthesia. Anesth Analg, 1991;72:275-281.

06. Schneider M, Ettlin T, Kaufmann M et al. - Transient neurologic toxicity after hyperbaric subarachnoid anesthesia with 55 lidocaine. Anesth Analg, 1993;76:1154-1157.

07. Drasner K, Sakura S, Chan V et al. - Persistent sacral sensory deficit induced by intrathecal local anesthetic infusion in the rat. Anesthesiology, 1994;80:847-852.

08. Bainton C, Strichartz G - Concentration dependence of lidocaineinduced irreversible conduction loss in frog nerve. Anesthesiology, 1994;81:657-667.

09. Pollock JE, Neal JM, Stephenson CA et al. - Prospective study of the incidence of transient radicular irritation in patients undergoing spinal anesthesia. Anesthesiology, 1996;84:1361-1367.

10. Pollock JE, Liu SS, Neal JM et al. - Dilution of spinal lidocaine does not alter the incidence of transient neurologic symptoms. Anesthesiology, 1999;90:445-450.

11. Tong D, Wong J, Chung F et al. - Prospective study on incidence and functional impact of transient neurologic symptoms associated with $1 \%$ versus $5 \%$ hyperbaric lidocaine in short urologic procedures. Anesthesiology, 2003;98:485-494.

12. Ben-David B, Maryanovsky M, Gurevitch A et al. - A comparison of minidose lidocaine-fentanyl and conventional-dose lidocaine spinal anesthesia. Anesth Analg, 2000;91:865-870.

13. Morisaki H, Masuda J, Kaneko S et al. - Transient neurologic syndrome in one thousand forty-five patients after $3 \%$ lidocaine spinal anesthesia. Anesth Analg, 1998;86:1023-1026. 


\section{Réplica}

\section{Senhor Editor,}

Com relação às considerações efetuadas pelo Dr. Imbelloni gostaria de ressaltar que:

- Neste modelo experimental em cães a lidocaína hiperbárica a $5 \%$ não desencadeou lesão sobre o tecido nervoso porque a injeção do anestésico local foi rápida, realizada em 10 segundos ${ }^{1}$, o que favoreceu a sua dispersão no líquor. Entretanto, em outra pesquisa, com o mesmo modelo experimental, na qual a lidocaína hiperbárica a $5 \%$ foi introduzida no espaço subaracnóideo de cães em injeções lentas (60 segundos), cuja finalidade foi dificultar a dispersão do anestésico no líquor, houve lesão de tecido nervoso em $25 \%$ dos animais estudados ${ }^{2}$.

- Já está bem estabelecido que a lidocaína hiperbárica a 5\% não deve ser utilizada em situações que favoreçam o seu acúmulo ou que propiciem a má distribuição, porque pode desencadear a síndrome da cauda eqüina (SCE), como descrito após a injeção subaracnóidea deste fármaco por meio de microcateter ${ }^{3,4}$ e de agulhas de ponta de lápis ${ }^{5,6}$ em injeções lentas ${ }^{5}$.

- Os fatores etiológicos potencialmente capazes de desencadear neurotoxicidade (altas doses e concentração de anestésico local) não são os mesmos que determinam os sintomas neurológicos temporários (SNT). Exames que possibilitam a avaliação da condução dos impulsos nervosos mostram que estes estão irreversivelmente alterados quando há neurotoxicidade ${ }^{7}$ e que são normais em pacientes com SNT ${ }^{8}$. Acredita-se que o SNT esteja associado à lidocaína porque este anestésico determina bloqueio neuromuscular intenso, propiciando estiramento músculo-esquelético quando o paciente assume a posição de litotomia, provocando o quadro clínico do SNT ${ }^{9,10}$.

Atenciosamente,

Eliana Marisa Ganem, TSA

Depto. de Anestesiologia da FMB de Botucatu

\section{Reply}

\section{Dear Editor,}

Regarding Dr. Imbelloni's observations, I would like to emphasize that:

- In this experimental model in dogs, 5\% hyperbaric lidocaine did not cause nervous tissue injury because the local anesthetic was administered rapidly, in 10 seconds ${ }^{1}$, which favored its spread in the CSF. However, in another study with the same experimental model in which $5 \%$ hyperbaric lidocaine was introduced slowly in the suba- rachnoid space of dogs (60 seconds) to hinder its spread in the CSF, $25 \%$ of the animals sustained nervous tissue injury ${ }^{2}$;

- It is well established that $5 \%$ hyperbaric lidocaine should not be used in situations that favor its accumulation or hinders its spread because it can trigger cauda equina syndrome, as described after the slow ${ }^{5}$ subarachnoid administration of this drug with a microcatheter ${ }^{3,4}$ and pencil-point needles ${ }^{5,6}$;

- The possible etiologic factors capable of triggering neurotoxicity (high doses and concentration of the local anesthetic) are not the same that cause the transient neurologic symptoms (TNS). The evaluation of the conduction of nerve impulses shows that it is irreversibly changed when there is neurotoxicity ${ }^{7}$ and that it is normal in patients with TNS ${ }^{8}$. It is believed that TNS is associated with lidocaine because this drug causes severe neuromuscular block, allowing for musculoskeletal stretching when the patient is in the lithotomy position, therefore causing the clinical picture of TNS ${ }^{9,10}$.

Yours truly,

Eliana Marisa Ganem, TSA, M.D.

Anesthesiology Department of FMB de Botucatu

\section{REFERÊNCIAS - REFERENCES}

01. Pires SRO, Ganem EM, marques M et al. - Efeitos de concentrações crescentes de lidocaína hiperbárica, administradas no espaço subaracnóideo, sobre a medula espinhal e as meninges. Estudo experimental em cães. Rev Bras Anestesiol, 2006;56:253-262.

02. Silva DM, Ganem EM, Marques M - Lidocaína hiperbárica a 5\% administrada pela via subaracnóidea com agulha de Quincke em diferentes velocidades de injeção. Efeitos sobre a medula e meninges. Rev Bras Anestesiol, 2004;54:(Suppl):249A.

03. Rigler ML, Drasner K, Krejcie TC et al. - Cauda equina syndrome after continuous spinal anesthesia. Anesth Analg, 1991;72:275-281.

04. Schell RM, Brauer FS, Cole DJ et al. - Persistent sacral nerve root deficits after continuous spinal anaesthesia. Can J Anaesth, 1991;38:908-911.

05. Beardsley D, Holman S, Gantt R et al. - Transient neurologic deficit after spinal anesthesia: local anesthetic mal distribution with pencil point needles? Anesth Analg, 1995;81:314-320.

06. Gerancher JC - Cauda equina syndrome following a single spinal administration of $5 \%$ hyperbaric lidocaine through a 25 gauge Whitacre needle. Anesthesiology, 1997;87:687-689.

07. Vianna PT, Resende LA, Ganem EM et al. - Cauda equina syndrome after spinal tetracaine: electromyografic evaluation 20 years follow-up. Anesthesiology, 2001;95:1290-1291.

08. Pollock JE, Burkhead D, Neal JM et al. - Spinal nerve function in five volunteers experiencing transient neurologic symptoms after lidocaine subarachnoid anesthesia. Anesth Analg, 2000;90:658-665.

09. Hampl KF, Heinzmann-Wiedmer S, Luginbuehl I et al. - Transient neurological symptoms after spinal anesthesia: a lower incidence with prilocaine and bupivacaine than with lidocaine. Anesthesiology, 1998;88:529-633.

10. Pollock LE, de Jong RH - Hyperbaric lidocaine for spinal anesthesia? Am J Anesthesiol, 1997;24:161-165. 